\title{
БОЛГАРСЬКА ЕТНОКУЛЬТУРНА ГРУПА ОДЕСИ: ДОСВІД СОЦІОКУЛЬТУРНОЇ АДАПТАЦІЇ
}

\author{
С. В. Коч, Г. Н. Стоянова
}

Коч C. В., Стоянова $Г$. М. Болгарська етнокультурна група Одеси: досвід соціокультурної адаптації. Предметом аналізу є особливості організації соціокультурного простору болгарської етнокультурної групи Одеси. Зазначено, що болгарське населення Одеської області, як традиційна етнокультурна група регіону, сформувалась упродовж XVIII-XIX ст. Сталі соціальні повсякденні практики створили основу подальшої адаптації в середовищі полікультурного міста, дозволили групі виступити активним учасником соціального простору в мегаполісі.

Ключові слова: етнос; болгари; адаптація; місто.

Коч С. В., Стоянова $Г$. Н. Болгарская этнокультурная группа Одессы: опыт социокультурной адаптации. Предметом анализа являются особенности организации социокультурного пространства болгарской этнокультурной группы Одессы. Отмечено, что болгарское население Одесской области, как традиционная этнокультурная группа региона, сформировалась в течение XVIIIXIX вв. Стабильные социальные повседневные практики создали основу дальнейшей адаптации в среде поликультурного города, позволили группе выступить активным участником социального пространства в мегаполисе.

Ключевые слова: этнос; болгары; адаптация; город.

Koch S. V., Stoynova G. N. The Bulgarian Ethno-Cultural Group of Odessa: Experience of SocioCultural Adaptation. The subject of the analysis is the specific features of the organization of socio-cultural space of the Bulgarian ethno-cultural group of Odessa. The authors noted that the Bulgarian population of Odessa region as a traditional ethno-cultural group of the region had formed during 18-19 centuries. Stable social everyday practices created the base for the further adaptation in the environment of the polycultural city, allowed the group to act as an active participant of the social space in megalopolis.

Keywords: ethnos; Bulgarians; adaptation; city.

Формування сучасної болгарської етнокультурної групи в Україні розпочалося в той час, коли територія сучасної Болгарії знаходилася у складі Османської імперії. Християнське населення, яке було обмежено у культурних та економічних правах, при переселенні в межі єдиновірної Російської імперії втрачало статус «меншини» і отримувало значні економічні пільги на цілинних землях Північного Причорномор'я. Болгари сприймали це переміщення як порятунок від релігійної і господарської асиміляції, як внутрішню міграцію. Процес переселення відбувався в межах «знайомого», семантично значимого простору, який відіграв значну роль в процесі етногенезу болгар в VII ст. Підвищення соціального статусу при переселенні, перспективи покращення соціального становища обумовили позитивні стратегії адаптації.

Протягом кінця XVIII - першої половини XIX ст. внаслідок декількох міграційних хвиль, спровокованих економічними та геополітичними війнами на Балканах, відбувалося формування болгарської спільноти на сході від Дунаю в степах Північного Причорномор'я ${ }^{1}$. У цей період основна маса болгар-переселенців - сільське населення, котре внаслідок державної політики безоплатно отримало землю і заснувало землеробські переселенські колонії. Висока адаптивна здатність болгар-колоністів була обумовлена належністю переселенців до однієї соціальної групи, а патріархальна форма організації групи створювала сталу систему соціальних внутрішньо-групових зв'язків. Важливо, що культурна відособленість виступала умовою отримання соціально-економічного статусу і пільг ${ }^{2}$. Колоністи, «освоюючи» новий простір, вписували біографію групи в регіональну історію краю. Відсутність власної національної держави, дієвість регіональної ідентичності, розселення в межах території історичного етногенезу обумовили значущість релігійного та господарського компонентів в структурі ідентифікаційного вибору. Надання етнічній ідентичності функції збереження соціальних кордонів і 
статусів в подальшому стало важливим чинником у формуванні стратегії розвитку групи на етапі переміщення в простір міста.

Ефективність адаптації етнічних громад була обумовлена груповим конформізмом переселенців, що опинилися в соціальному просторі, формування якого відбувалося за їх участю. Відчуття «соціального миру» в цих умовах було здатне існувати тільки на базі соціального ресурсу, яким група володіла в момент переселення.

Практика групової адаптації визначила вибір і закріплення за групою господарської ніші, яка відповідала особливостям традиційного сектору господарювання. Група, формуючи життєвий простір, пристосовувала до нових природно-географічних і соціальногосподарських умов власні навички виживання. Спеціалізація в перспективних галузях економіки забезпечила закріплення за групою «права на присутність / проживання», тобто колективне право на життєвий простір, що відображено в топоніміці регіону і його іконографії. Отже, вписування історії групи і групової ідентичності в регіональну, імперську та національну історію проявилося у вигляді ідентичностей, таких як «бессарабець», «бессарабський болгарин», «таврійський болгарин» або локальних за місцем походження «чийшийці», «кубейці» ін. Слід зазначити стійкість такої ідентичності у груп навіть після переселення в місто або виселення з регіону..

Так, руйнація традиційного господарського сільського укладу, що набула лавиноподібних форм в 80-90 pp. ХХ ст. в період кризи, призвела до активного переселення болгар в місто. Сталість та структурованість соціокультурного простору бессарабської діаспори стали запорукою успішної адаптації у новому, незвичному урбанізованому середовищі.

Будучи відносно новою групою в етнічній структурі населення Одеси, бессарабські болгари спиралися на систему групової соціальної допомоги у вигляді земляцтв. Спостерігається наступна тенденція: як на перших етапах переселення на терени України, так і на сучасному етапі, помітну роль у пристосуванні до нового простору відіграють стабільні внутрішньо-групові зв'язки, які стають основою для формування соціальних мереж.

Переселяючись 3 села в місто, болгари розраховують на допомогу (пошук помешкання, працевлаштування, проведення дозвілля) земляків - попередників. Спільна групова ідентичність, дозволяє формувати «етнічні» соціальні мережі, скорочує можливі «трансакційні витрати», що пов'язані із недовірою незнайомого середовища, комерційним ризиком, необхідністю використання посередників ${ }^{3}$. Виходячи 3 тези про те, що локальне етнокультурне середовище - це місце реалізації повсякденних практик, які спрямовані на досягнення соціального результату, зрозуміло, що рівень етнізації соціального простору передбачає потенційні можливості групи адаптувати нових мешканців зі спорідненого культурного простору ${ }^{4}$.

Неформалізована соціально-культурна структура у вигляді земляцтв $є$ зручним засобом контрольованої взаємодї, яка базується на «довірі» в середині споріднених груп і спрощених механізмах контролю. Такі соціальні структури стають ефективним засобом лобіювання особистих і групових інтересів в просторі міста, що функціонує як полікультурна, багатолика система, з укоріненим механізмом резервування соціально-економічного простору групами. Така культурна система мегаполіса стимулює групи до того, щоб бути представленими у просторі міста.

Ефективне існування болгарських земляцтв в Одесі стало помітним уже в 1990-ті роки. На сучасному етапі інтенсивне зростання кількості земляцтв болгар-вихідців з бессарабських сіл можна спостерігати в інтернет-просторі. Моніторинг існуючих спільнот у популярних соціальних мережах («В контакте», «Одноклассники», «Фейсбук») показав, що: 1) групи, які створюють болгари для спілкування, $є$ відкритими та масовими; 2) принцип їх формування полягає передусім в регіональній, локальній належності; 3) завданням таких груп $є$ відтворення етнокультурного середовища в нових умовах 5 .

Так, мережа «В контакте» містить: 1. Об'єднання за етнічно-регіональним принципом: група «Болгары Одесской области» (1973 учасник) (http://vk.com/odessabulgaria); група «БолгарЫ Бессарабии» (http://vk.com/besarabski_bulgari) (5981 учасник). 2. Об'єднання за локальним принципом (місце фактичного проживання та/або місце народження): група «БОЛГРАД!!!!» (2789 учасник) (http://vk.com/club456970); група «Кубей Лучший» (382 учасник) (http://vk.com/club8319376); «ТРОЯНЦЫ всегда и везде!!» (422 учасник) (http:// 


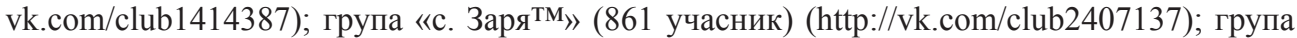
«Новая Ивановка» (413 учасник) (http://vk.com/club4545886); «Славното село Чийшия» (908 учасник) (http://vk.com/gorodnee); група «БЪЛГАРСКО СООБЩЕСТВО “Главанска Мафия "м"» (2575 учасник) (https://vk.com/glavanska_mafia) та ін.

Більшість груп, що створені у соціальній мережі, $є$ переважно російськомовними, де тільки певна кількість діалогів ведеться болгарською. Згідно з переписом 2001 р., 64,2\% українських болгар назвали рідною мовою «болгарську», але фактично етнічна мова обслуговувала переважно побутову сферу життя, в той час як публічними мовами виступали російська, румунська, українська. Кожне з чотирьох поколінь сучасних болгар отримувало освіту на різних державних мовах. Таке становище пояснює факт сталої двомовності або навіть тримовності у болгар, котрі сьогодні мешкають в місті Одеса.

Новітні процеси консолідації групи в умовах міста та зростання престижу болгарської ідентичності обумовлюють поступове розширення функції болгарської мови, яка викладається не тільки на курсах, в школах, але й в університеті (розвивається публічна та інформаційна сфера болгарською мовою). Таке положення вплинуло й на інтернетресурси, де деякі групи в повсякденних діалогах і в поданні публічної інформації перейшли на болгарську мову. Наприклад, група «Славното село Чийшия» (http://vk.com/ gorodnee).

Крім комунікаційних проблем, етнічні групи в соціальних мережах виконують акумулятивну функцію, забезпечуючи презентацію та трансляцію локальних сімейних і групових цінностей. Активна меморіальна поведінка членів таких груп є наслідком ностальгічних переживань та бажання створити навколо себе соціальну мережу, де співпричетність до загальної культурної спадщині стає умовою для взаємної допомоги у вирішенні спільних соціальних завдань. Намагання відтворити історію своїх сіл, створення фото-літописів за рахунок викладання у мережу сімейних фото, інтерпретація історичних подій, які пережили власні родини, - все це спрямоване на підтримку позитивної ідентичності локальної групи й окремих іiї представників. Такі практики локальної коммеморативної поведінки дозволяють членам етнічних земляцтв формувати та транслювати досвід раціонального використання ідентифікаційних характеристик.

Цінність таких «локальних історій» - в обмеженій публічності, у відсутності будьяких настанов та санкцій з боку національних центрів (як приймаючого національного, так і етно-національного). Напрям розвитку такої «групової історії» демонструє реальний соціальних рух групи. В «болгарських» соціальних мережах активними темами для обговорювання є: «Български фамилии», «Ностальгия по родному селу», «Історія села», "Для тех, кто уехал из Зари, но болезненно скучает...», «Любимое место в селе...», «Наши земляки...». Популярними темами для обговорень $\epsilon$ ті, котрі спрямовані виявити ступінь обізнаності щодо болгарських традиційних страв, свят та деталізація їх побутування завдяки власному сімейному досвіду: «Баница», «Как у вас отмечают Великден?», «Понравилось ли вам в Заре на "Храме"?».

Етнізація групової історії болгар Одещини демонструє процес актуалізації етнічної ідентичності та зміцнення етнічного кордону. Таким чином відбувається закріплення певного уявлення про минуле, а особисті спогади співвідносяться із культурною самобутністю, що стає основою для віднесення себе до певної ідентичності.

В соціальних мережах не тільки минуле - мала Батьківщина, культурні символи; тут спільні нові проблеми, які представлені в темах для обговорення в рекламі та в оголошеннях: «Попутчики и попутный транспорт. Экономим вместе на бензине!!!», «Доска объявлений!!! Кто, что продает? хочет купить и т.д.!!!».

Окреме місце посідають повідомлення щодо взаємодопомоги будь-якого характеру, будь то в оформленні документів на виїзд до Болгарії, громадянства або сприяння у влаштуванні на роботу, пошук житла, купівля-продаж різних речей і навіть пошук попутників під час поїздки додому («Пусть на Пасху одесситы поймут как мало их осталось...»; «Делаю Болгарское гражданство по происхождению болгарам, гагаузам, македониам!!!»; «Преимущества второго гражданства Болгарии!!!»).

Позитивна групова пам’ять - це передумова соціальної активності групи. Колективна пам'ять обумовлює створення певних моделей поведінки, забезпечує дієздатність групи в процесах відтворення міжпоколінних зв'язків, впливає на прийняття соціально значимих 
рішень. Будь-яка етнокультурна група в соціальному просторі обирає такі варіанти реконструкції минулого, які мінімізують травматичний вплив політичних процесів.

Так, механізмом створення позитивного «іміджу» для болгар Одещини стало створення такого образу групи, який би дозволяв їй бути впізнаною та соціально значимою. Презентація групових відмінностей, цінностей виступає як засіб резервування соціального простору. На сучасному етапі активно відбувається таке «резервування» в просторі міста.

Внаслідок формування розвинутих форм самоорганізації в Одесі група болгар отримала можливість зберігати відносну самодостатність, демонструючи здатність і готовність здійснювати свій соціальних захист, лобіювати інтереси співвітчизників в Україні та Болгарії. Основою цієї соціально-культурної інституалізованої системи є об'єднання етнічних болгар із загальноукраїнським статусом: «Асоціація болгар України» (1993, А. Кіссе), «Конгрес болгар України» (2007, Ю. Граматик) та «Всеукраїнська асамблея болгар України» (2013, Д. Костова). Всі три організації зареєстровані в Одесі. Кожна з них володіє розгалуженою системою соціальних і політичних зв>язків, які формують мережеву соціокультурну систему транснаціонального масштабу ${ }^{6}$.

Так, Асоціація болгар України з 2008 року входить до складу Союзу болгар Європи, співпрацює з Національними фондами «Христо Ботев», «Васил Левски», «Мати Болгария», «Тангра ТанНакРа». За участю асоціації 2015 р. в Болгарії створено Координаційний центр для зв'язку з болгарами України ${ }^{7}$. Асоціація $\epsilon$ ініціатором встановлення соціальнокультурних і комерційних зв'язків з етнічними групами болгар в інших країнах ${ }^{8}$, проголосивши головним завданням включення в процес інтеграції регіональних діаспор, які, на відміну від бессарабських болгар, тільки набувають досвіду репрезентації своїх інтересів. Також організація займається збереженням і розвитком історичних цінностей, національної культури, мови і традицій, сприяє реалізації прав та свобод болгар в Україні. Асоціація має друкований орган - всеукраїнський щотижневик «Обозрение плюс» ${ }^{9}$.

Конгрес болгар України в особі Ю. Граматика з 2008 р. є учасником Всесвітнього парламенту болгар і Асоціації болгар світу. Конгрес відомий як меценат культурно-просвітницьких центрів «Аз Буки Веди» в Одесі, Ізмаїлі, Іллічівську, Болграді. Центри діють за фінансової підтримки Міністерства освіти, молоді та науки Болгарії в рамках програми «Роден език и култура зад межа». Основою метою організації «Конгрес болгар України», вважає Ю. Граматик, є зменшення рівня асиміляції болгарського населення. Як він зазначив в одному із своїх інтерв'ю, молодь болгарського походження в Україні переїжджає із сільської місцевості в міста Одесу, Іллічівськ, Київ, де переважає російськомовне населення, і коли справа доходить до змішаних шлюбів, діти вже 3 малих років не знають болгарську мову і традиції. Більшість 3 них втрачають болгарську ідентичність ${ }^{10}$. У 2013 р. в Одесі за підтримки Конгресу було відроджено Болгарський драматичний театр. За словами його художнього керівника С. Садаклієва, мета колективу полягає в тому, «щоб болгарин, який приїхав навчатися, праџювати або вже давно живе в Одесі, міг пишатися своєю національністю, мав можливість в один прекрасний вечір прийти в наш театр $i$ подивитися виставу рідною мовою» ${ }^{11}$. Профінансував Конгрес болгар України й щойно видану у Харкові енциклопедію «Болгари в Російській імперії, СРСР, країнах Балтії та СНД», де, зокрема, розміщено понад 100 персоналій одеських болгар ${ }^{12}$.

Третя організація - «Всеукраїнська асамблея болгар України»-зареєстрована в Одеci 28 березня 2013 р. Її президент Д. Костова була засновником ВОО «Конгрес болгар України» й ініціатором створення Асоціації болгар України, головним редактором газети «Роден край» ${ }^{13}$.

Крім того, в Одесі в липні 2014 р. зареєстрована громадська організація «Болгарське народне зібрання», яка своєю метою проголосила об'єднання всіх болгар України, а також формування взаємовідносин між органами влади і національно-культурними організаціями болгар. Така мета свідчить про намагання створити певну лобістську структуру, котра б дозволила успішно репрезентувати інтереси членів групи, їх культурні та бізнес-інтереси ${ }^{14}$. У планах цієї громадської організації - відкриття в Одесі болгарського комплексу, до якого увійдуть навчальний заклад, інтернат для дітей і храм, як символ єднання болгар. Такі плани розростання інфраструктури для забезпечення соціальних потреб болгарського населення свідчать про інтенсивний розвиток етнокультурної спільноти в межах міста. 
Традиційними для Одеси є такі інфраструктурні об'єкти болгарської спільноти, як Одеське болгарське товариство (дружество), що діє з 1989 р., бібліотека імені Івана Вазова (з 1998 р.), Всеукраїнський центр болгарської культури (з 1999 р.), Одеський обласний Союз болгарської молоді (з 2001 р.) Болгарський молодіжний клуб «Актив» (3 2009 p.).

Їхня діяльність охоплює різні соціальні групи етносу, представлені у місті: діти, молодь, вчені, митці, громада. Освітні програми з вивчення історії, культури та мови надають можливість компенсувати відсутнє в місті етнокультурне середовище, підготуватися до навчання, зокрема в Болгарії. Важливим елементом консолідації групи і підтримання комунікаційної сфери є організація дозвілля для болгарської молоді Одеси. Так, традиційними для міста стали такі проекти, як «Бессарабская лига КВН», «Вечеринка "Болгарский перчик”», «День славянской письменности и культуры», «Мисс-Болгарка», «Мистер Болгарин», «Футбольний турнир Конгреса болгар Украиныл», «Баница», «День независимости Болгарии» та ін. Цікавим є той факт, що на міські майданчики перенесені святкування господарських календарних дат: «Трифон Зарезан», «Баба Марта» тощо. Отже, простір міста стає частиною організації свят. Зокрема, традиційним стало прикрашання «мартеничками» дерев у центрі Одеси.

Інтелектуальний та творчий потенціал спільноти реалізується за рахунок проведення традиційної Кирило-Мефодіївської конференції та інших наукових форумів: «Болгари Північного Причорномор'я», Вазовські та Ботевські читання й тематичних виставок (наприклад, виставка фотографій «Бесарабські болгари: хроніка століття»), музейних експозицій (болгарська зала в Літературному музеї Одеси) та ін.

В історію найстарішого університету Півдня України - Одеського національного університету імені I. I. Мечникова - вписані імена видатних болгар та болгаристів: А. Констанинова, Г. Згурева, Д. Тончева, С. Муткурова, В. Григоровича, І. Дузя, А. Смольської, Б. Шайкевича, В. Станко. Останнім 1993 року на історичному факультеті ОНУ була створена кафедра археології та етнології України, що перетворилася на один із авторитетних центрів вивчення болгарської діаспори. Вже понад двадцять років існує болгарське відділення при філологічному факультеті ОНУ, на якому 1995 р. відкрилась спеціальність «болгарська мова та література», що зумовлено активізацією процесів відродження мов національних меншин, необхідністю підготовки кадрів для засобів масової інформації, культурних установ та шкіл, де вивчається болгарська мова. Представники історичної та філологічної болгаристики 1995 р. об'єднались в межах Одеського наукового товариства болгаристів, що має друкований орган - щорічник «Одеська болгаристика». Постійним місцем зібрання як болгаристів, так і окремих болгарських громад, зокрема Чійшийської найстарішої та найбільшої за кількістю став Центр болгарської культури Одеси.

Взагалі в Україні зареєстровано понад 70 осередків болгар, з них більше двох десятків функціонує в Одеській області. Така мережева структура етнічної групи дозволяє їй виконувати роль соціально мецената, реалізуючи громадські, культурні та економічні потреби. Мережеві етнокультурні системи сьогодні здатні виступати альтеративними структурами до офіційних державних інституцій в питаннях соціального і культурного забезпечення. Допомогу в діяльності етнокультурних організацій надають суб'єкти господарювання, керівники яких зацікавлені в підтримці культурного середовища болгарської групи. Ще 2003 року Асоціація болгар України вказала на більше 30 таких організацій ${ }^{15}$.

Мережа соціально-економічних об’єктів, якими володіють болгари в Україні, сприяє реалізації економічного потенціалу в різних сферах господарської діяльності: будівництві, медицині, транспортному сполученні, сільському господарстві, торгівлі тощо. Успішно працюють понад 20 україно-болгарських підприємств і товариств, котрі створені для забезпечення соціально-економічних потреб болгар або засновниками яких виступають особи болгарського походження. В Одесі до них можна віднести ПКФ «Лазурь», дочірнє підприємство болгарського ООО «Валимарк», Українсько-болгарське підприємство «Одеса-Варна», ТОВ «Варна ЛТД», Українсько-болгарське торгове підприємство «Ніки СП», ТОВ «Українсько-болгарська будівельна компанія» та ін.

Господарські підприємства часто-густо виступають меценатами при реалізації громадських ініціатив. Наприклад, відкриття болгарської зали Літературного музею у червні 2016 року відбулось за підтримки генерального директора ПАО «Одескабель» Дмитра 
Йоргачева; встановлення пам’ятної дошки Василу Априлову - за підтримки Валерія Твердовського, директора розважального комплексу «Zимний». Його брати Василь та Петро Твердовські підтримують практично всі розважальні заклади болгарської діаспори Одеси, надаючи майданчики клубів «Паладіум» та «Ітака», що їм належать.

Громадські організації, в свою чергу, лобіюють інтереси підприємців-співвітчизників в органах державної влади і місцевого самоврядування. Так, за сприяння Асоціації болгар України відома в Болгарії компанія з виробництва моторних масел «Пріста Ойл Холдінг» 2001 р. зареєструвала в Україні дочірнє підприємство «Пріста Ойл», яке реалізувало інвестиційний проект в Одеському морському порту: в 2004 році був відкритий сучасний комплекс по зберіганню, перевантаженню і додатковій обробці базових масел. У 2007 році ця фірма подарувала місту пам'ятник Кирилу і Мефодію як символ дружби між Україною і Болгарією. 2003 року за участі Асоціації болгар України відкрита Українсько-болгарська клініка кардіохірургії як філія університетської клініки «Свята Катерина» м. Софія. Дмитро Йоргачев допоміг оснастити їі медичним обладнанням, про що йдеться на сайті клініки ${ }^{16}$.

Масштаби та результати соціально-культурної діяльності наочно видно під час проведення Собору болгар України (з 1998 р. проведено 7 таких заходів), що збирає водночас декілька тисяч болгар. Собори проводяться за ініціативою Асоціації болгар й завдяки підтримці бізнес-еліти болгарського походження в Україні. Меценати, спонсори, науковці, просвітники, культурні діячі в середовищі болгарської етнічної групи отримують визнання у вигляді почесного звання «Людина року» під час щорічної церемонії, яку проводить Асоціація болгар України, або під час Собору болгар, коли відбувається нагородження громадян України (болгарськими орденами «Мадарски конник», «Стара планина», Святих Кирила і Мефодія, Паїсія Хілендарського, Почесним знаком Президента Болгарії, медаллю «Іван Вазов»).

Інформаційний простір та комунікаційне середовище болгар Одещини структурується і завдяки 3MI: 32013 року видається обласний культурно-просвітницький щотижневик «Българите вчера, днес, утре»; з 2001 року щотижнево виходить всеукраїнський державний культурно-просвітницький вісник болгар «Роден край», а також «Одеські вісті», «Дунайські вісті», «Обозрение плюс» та ін. Вони акумулюють ініціативи й координують діяльність усієї регіональної структури. На обласному телебаченні виходять щотижневі (26 хвилин) програми «Роден край» (болгарською мовою), «Колорит» (болгарською й молдовською мовами, почергово). У телепередачі «Інтер-Одеса» щотижня (26 хвилин) висвітлюється діяльність національних товариств Одеської області ${ }^{17}$.

Отже, взаємозв'язок між спорідненими групами різних регіонів і країн створює можливості для соціальної дії, лобіювання інтересів певних груп. На чолі мережевої структури болгарських груп де-факто знаходиться Асоціація болгар світу, хоча на нормативноюридичному рівні такий зв'язок не оформлений.

Соціальна активність болгарської етнокультурної групи в Одесі проявляється через створені механізми, передусім меморіальну практику і соціальне лобіювання. Так, у міському ландшафті з'явилась значна кількість місць, які закріплюють «присутність» групи у соціальному просторі. Зокрема, в місті встановлені пам’ятники Кирилу і Мефодію (на центральній алеї Одеського національного університету, що на Французькому бульварі), Христо Ботеву (в Прохоровскому сквері); меморіальні дошки Івану Вазову (вул. Софієвська, 32-34), Христо Ботеву (вул. Новосельского, 93) і Василу Апрілову (вул. Буніна, 29). В місті широко представлена болгарська кухня, навіть діють етнічні кафе: «Механа», «Бессарабський дворик», «Бессарабка» та ін. Регулярно проходять виставки митців болгарського походження, організуються зустрічі для потенційних абітурієнтів у вищі навчальні заклади Болгарії. Нещодавно, наприклад, Пловдивський університет імені Паїсія Хілендарського проводив активну кампанію по залученню на комп'ютерні та інші спеціальності студентів-болгар з Одеси. Взагалі, 2016 року Болгарія більш ніж в два рази збільшила кількість місць для українців болгарського походження в навчальних закладах країни. Інтерес з боку одеських школярів та абітурієнтів викликаний перспективами проживання в країні СС і економічною кризою в Україні. Можливість для випускників болгарських шкіл Одеської області здобувати освіту безкоштовно в університетах Болгарії зумовлює вибір молоді, сприяючи зростанню імміграції в Болгарію кваліфікованих співвітчизників. 
Меморіальні об'єкти, культурні і соціальні заходи дозволяють транслювати бажаний змістоутворюючий образ спільноти. Болгарська ідентичність в місті закріплюється за рахунок створення етнокультурного соціального середовища, а символізація простору маркерами «своєї» культури дозволяє конструювати реальність, визначати і закріплювати діючи ієрархії в структурі політичної влади та соціальних відносин.

Болгари Одещини за останні роки відчули зацікавленість з боку Болгарії, що проявляється в регулярних візитах представників державних органів та інституцій - як культурних меценатів і спонсорів багатьох проектів. Так, 16 лютого 2015 р. в перебігу зустрічі прем'єр-міністра Болгарії Бойко Борисова 3 Антоном Кіссе прийнято рішення про створення в будинку Державної агенції болгар за кордоном м. Софія Координаційного центру для зв'язку з болгарами України з метою надання їм допомоги у зв'язку зі складною ситуацією в країні ${ }^{18}$. Крім того, в рамках розширення контактів болгар України із етнічною Батьківщиною Болгарія створила програми розширення паломницького туризму, пільгового навчання для дітей болгарського походження й таке інше.

Структурованість болгарської соціокультурної системи перетворює групу у зручний об'єкт електорального впливу і політичних маніпуляцій, надає можливість від імені групи претендувати на застосування механізмів групової дії (колективні звернення, групові протести та ін.).

Представництво етнічної групи болгар в органах державної влади сьогодні забезпечується різними шляхами. Найпомітнішою є участь у виборчих компаніях діячів етнічних громад і культурних товариств. Політична кар'єра таких лідерів будується на активному лобіюванні інтересів територіальної етнокультурної громади або регіону. В Одеській обласній раді VI скликання було створено депутатську групу «Бессарабія». Політична кар'єра політиків нової генерації пов'язана із презентацією інтересів болгарської групи в Одесі і Одещині. У політичній кар'єрі таких лідерів власна етнічна ідентичність $\epsilon$ підставою для отримання довіри з боку групи, яка делегує «свого лідера» у владу. Так, лобістами інтересів болгарської соціально-культурної спільноти можна вважати I. Плачкова, А. Кіссе, Ю. Граматика, М. Попову, М. Габера, А. Самунжі й деяких інших.

Отже, накопичений досвід вдалої адаптації в межах південних регіонів Причорномор'я, створення організованої структури між багатьма групами болгар як регіону, так і світу, обумовили швидке і ефективне «проникнення» мережевої етнокультурної системи в соціокультурний простір міста. Накопичений досвід адаптаційного процесу виявився ефективним на різних рівнях, а саме на макро-рівні (включення соціокультурних інституцій болгар України в глобальну мережеву структуру болгар світу) і на мікро-рівні (активна інтеграція болгар на індивідуальному рівні в соціальну структуру Одеси). В просторі міста активно розгорнутий діалог між значущими агентами етносоціальної групи: 3 одного боку, це підприємці, економічні агенти, науковці, які відтворюють етнічне (мову, етнокультурні об'єкти, господарчі практики), а з іншого боку, - «споживачі» етнічного, відвідувачі ресторанів, музеїв, театру, шкіл тощо. Болгарська культура та продукти культури стали складовими «товарів» та «послуг», що свідчить про глибоке проникнення в соціокультурну складову поліетнічного міста.

${ }^{1}$ Бернштейн С. Б. Основные этапы переселения болгар в Россию в XVIII-XIX вв. // Советское славяноведение. - 1980. - № 1. - С. 42-59.

${ }^{2}$ Коч C. B. Социально-экономические модели адаптации этнических групп (на примере «старых» и «новых» диаспор юго-западного региона Украины) // Предупреждение насильственних конфликтов в мультикультурных сообществах и формирование культуры мира: Сб. научн. трудов / Крымское отделение Института востоковедения имени А. Е. Крымского НАН Украины. - К.: ЧП «Золоті Ворота», 2011. - С. 61-71.

${ }^{3}$ Бредникова О. Этничность «этнической экономики» и социальные сети мигрантов / О. Бредникова, О. Паченков // Этничность и экономика: Сб. статей по материалам международного семинара. - Вып. 8 / Под ред. О. Бредниковой. - СПб.: ЦНСИ, 2000. - С. 49.

${ }^{4}$ Коч C. Этническое лоббирование как социальная практика в пограничье (на материалах исследования Бессарабии) // Перекрестки. Журнал исследований восточноевропейского Пограничья. -2014 . - № 1. - C. 55. 
${ }^{5}$ Стоянова Г. Н. Репрезентация этничности в социальных сетях: конструирование реальности и идентичности (на примере этнических групп Одещины) // Постфактум: історико-антропологічні студії. - 2013. - № 1 - С. 72-82.

${ }^{6}$ Всеукраїнська громадська організація «Асоціація болгар України» // Реєстр громадських об’єднань в України - URL: http://rgo.informjust.ua/ (дата звернення: 22.08.2016 ); Всеукраїнська громадська організація «Конгрес болгар України» // Реєстр громадських об'єднань в України - URL: http://kbg.org.ua. (дата звернення: 22.08.2016)

7 Премиерът Борисов: Координационен център ще поддържа постоянна връзка с българите в Украйна // Республика България. Министерски Съвет - URL: http://www.government.bg/cgi-bin/ecms/vis/vis.pl?s=001\&p=0212\&n=3406\&g=. (дата звернення: 15.08 .16 )

${ }^{8}$ Всеукраїнській болгарській асоціації- 10 років. - Одеса: Маяк, 2003. - С. 68-69.

${ }^{9}$ Обозрение плюс. Общественно-политический еженедельник - URL: http://obozrenie-plus.com. (дата звернення: 22.08.2016)

10 Железкова А. Юрий Граматик: Нашата основна цел е борба с асимилацията на българите в Украйна // Информационна агенция «Фокус» - URL: http:/www.focus-news.net/?id=f20743. (дата звернення: 15.08.16)

11 Одесский Болгарский Драматический театр. Официалный сайт театра - URL: http://www. bgteatr.od.ua/o-nas/. (дата звернення: 22.08.2016)

${ }^{12}$ Станчев М. Болгары в Российской империи, СССР, странах Балтии и СНГ. - Т. 2: Биографическая энциклопедия. - Харьков, 2016. - 592 с.

13 Громадська організація «Всеукраїнська Асамблея болгар України» // Реєстр громадських об’єднань в України - URL: http://rgo.informjust.ua/. (дата звернення: 10.08.16)

${ }^{14}$ Болгарское народное собрание. Официальный сайт - URL: http://ua-bg.com. (дата звернення: 11.08.16)

${ }^{15}$ Всеукраїнській болгарській асоціації - 10 років. - Одеса: Маяк, 2003. - С. 69-70.

${ }^{16}$ Клиника Святой Екатерины. Официальный сайт - URL: http://svekaterina.ua/about. (дата звернення: 20.08.16)

17 Третя періодична доповідь України про виконання Європейської хартії регіональних мов або мов меншин. - К., 2015 - 204 с. - URL: http://www.coe.int/t/dg4/education/minlang/Report/ PeriodicalReports/UkrainePR3 ua.pdf. (дата звернення: 10.08.16)

18 Премиерът Борисов: Координационен център ще поддържа постоянна връзка с българите в Украйна. Республика България. Министерски Съвет - URL: http: // www.government.bg/cgi-bin/e$\mathrm{cms} /$ vis/vis.pl? s=001\&p=0212\&n=3406\&g=. (дата звернення: 21.08.16) 